\title{
On the Teaching Strategies of Communication Courses under the Background of Media Convergence
}

\author{
Xin Zhang ${ }^{*}$ \\ Tiantian Paiding Media Co., Ltd. E-mail: zhangx@163.com
}

\begin{abstract}
In order to cope with the great changes in media integration, journalism education in colleges and universities is seeking reform and breakthrough. Communication is the basic theoretical course of news communication. The author finds that in teaching practice, with the acceleration of the process of media integration, more and more students misunderstand the communication science, and think that the communication theory is "outdated", and the tendency of media integration is "out of touch", which has a great influence on teaching.
\end{abstract}

Keywords: Media Integration; Journalism and Communication; Curriculum

\section{The integration of communication courses and media}

Communication course is a basic theoretical course of news communication. It mainly investigates various human communication activities and phenomena, and guides more effective communication behaviors by studying and summarizing the laws of communication. Communication is a real "foreign product" introduced into China in 1970s. This course is offered by colleges and universities to help journalism students master the basic theories and communication skills of communication science, implement communication strategies and communication skills in business practice, and lay a good foundation for students to enter the society and workplace smoothly after graduation. However, the communication course itself is very theoretical, and it is difficult to teach, understand and learn, which often puzzles teachers and students.

In the author's teaching, three majors of news editing, radio and television and visual communication were investigated. In order to better understand the present situation of communication education, $78.43 \%$ of the students think that communication major contains many theories and obscure words; $56.2 \%$ of the students think that communication is a practical subject. In order to understand the current teaching situation of communication more clearly, they often think that communication theory is an "outdated" major, which is out of touch with the existing new media era and tends to be a phenomenon of media integration. However, students who intend to take the postgraduate entrance examination choose to think that journalism is more capable than communication. As an important theoretical course, communication is facing severe challenges. Therefore, it is feasible to re-examine the communication process under the background of media integration.

2014 is generally considered as "the first year of China's media integration", because its strategy of developing media integration has been officially strengthened in China. On August 18, 2014, General Secretary Xi Jinping presided over the meeting of the leading group of the Comprehensive Reform Center, reviewed and approved the guidance on accelerating the integration of traditional media and emerging media, and delivered an important speech, providing

Copyright (C) 2020 Xin Zhang

doi: $10.18686 / \mathrm{mcs} . v 2 \mathrm{i} 4.1363$

This is an open-access article distributed under the terms of the Creative Commons Attribution Non-Commercial License

(http://creativecommons.org/licenses/by-nc/4.0/), which permits unrestricted non-commercial use, distribution, and reproduction in any medium, provided the original work is properly cited. 
strategic guidance and action guidelines for strengthening media integration in the new stage. Media integration is the collection and evolution of media industry in media form, media function, means of communication, capital ownership and organizational structure. It not only shows the integration process of these elements, but also the integration of news production process, and also means the unity of information services provided by news products in the forms of text, audio, images, videos and numbers. In a sense, media integration is a new form of communication, which changes people's information habits, and this change will bring opportunities and challenges to the teaching of communication courses.

\section{The current situation of experimental teaching reform of communication under the background of media convergence}

With the popularization of communication technology and intelligent terminal, the content, platform and channel all show the tendency of integrating new and old media. "Media integration" is no longer an obscure term, but a real feeling of ordinary people in reality. Based on the traditional journalism and communication industry, the journalism major is facing the rapid development of new media, and is also undergoing major changes. Academician Cai Wei pointed out that in the era of media integration, news communication training should train editors of journalists who can use various technical means.

In view of the current state of media integration, many colleges and universities try to cultivate complex and comprehensive abilities with a complete media perspective from single media practice to comprehensive inter-media education to meet the needs of real media. Despite efforts to seek breakthroughs, there are still many problems in the experimental link in the actual reform process: Firstly, the teaching content can be outdated and not integrated with the new state of the industry for improvement; In addition, teachers report the lack of high-quality experimental teaching materials that meet their professional characteristics, and often refer to computer, art design and other teaching materials in the teaching process, and then modify the textbooks according to their professional requirements, which is time-consuming and labor-consuming. According to the background of media integration, the innovative structure of experimental teaching materials can optimize the teaching content, change the teaching mode, encourage the implementation of the reform, reflect the reform results and play the role of innovative ability in practice.

\section{Problems in communication teaching practice under the background of media convergence.}

\subsection{Unpractical teaching goal}

When formulating communication courses, colleges and universities have a comprehensive understanding of the open education goals such as the communication theory between China and the West and systematic study practice, so that students can use the development of communication, various theories, factions and, more importantly, communication knowledge to train students to think, analyze and improve their abilities in various practices. However, there is a certain gap between the goal of cultivating talents with this ability and the ability needed for media integration. Media integration inevitably requires the integration of journalists' skills, the gradual integration of reporting styles, and the complementarity of news expression. At the same time, the news gathering process must be coordinated for this purpose, which also requires new skills for journalists to deal with news. Therefore, the "single-minded" ability in the traditional sense can no longer adapt to the media integration state of news production, and professional skills should also be integrated into journalists to become "one person with many talents”, "versatile” and even "band conductor” talents.

\subsection{Relatively outdated teaching content}

Among many communication textbooks, the most popular textbooks are Shao Peiren's Communication, Guo Qingguang's Communication Course, Hu Zhengrong's Introduction to Communication, Sun Geng's Introduction to 
Communication, etc. Objectively speaking, “all changes are the same” in basic theoretical books there such as teaching materials is a certain lag. From the research content of communication studies, most communication courses focus on Lasswell's “5W” communication model, namely control analysis, content analysis, media analysis, audience analysis and effect analysis. From the perspective of teaching process, teachers often rely on teaching materials, covering everything from beginning to end, and will not adjust the teaching content according to the actual situation of students, especially the general trend of media integration, and fail to integrate relevant information into this teaching material. For example, “central kitchen”, a news planning platform for Shandong radio and television media, has been officially put into use. For example, Shandong news network, public channels, lightning news and many other channel resources have gathered together to realize interview, classified production, directional push and multi-screen release. The experience of Shandong media news platform is worth learning from professional teachers in colleges and universities. If the latest application can be summarized as a theory and given to students, the teaching effect will be greatly improved.

\section{Strategies of communication teaching and learning under the back- ground of media integration}

\subsection{Innovative education and teaching philosophy}

The initial teaching of communication is mainly to ensure that students understand the phenomenon of communication and the dissemination of information and master the law of communication, so as to provide professional talents for traditional media such as newspapers, radio and television. With the development of the times, facing the integration of media, all kinds of media have become history, and integrated development is the main way. Due to the late starting point and fierce competition, there is an urgent need for a large number of Chinese diversified and compound media talents to study the way while taking the road of integration. Colleges and universities must follow the development trend, develop the concept of education and training, put communication at an important position in research, and carry out curriculum setting and curriculum preparation according to the actual situation of the school. Nothing is more practical than a good theory. Therefore, communication in teaching should not be "abstract theoretical research", but "always adhere to the rapid changes in economic, cultural and social development, the communication concept of professional concern, the optimization and integration of communication teaching content and interactive and flexible teaching methods".

\subsection{The development path of three-dimensional teaching materials}

The development of three-dimensional teaching materials is a complex process with the characteristics of diversified media forms, dynamic teaching content and specialized structure system, which makes it more reasonable to complete this work through teamwork. An effective three-dimensional teaching construction team organization cannot be separated from the coordination of university leaders. The ideal construction team includes news tion backbone teachers, teaching assistants and students, and professional company employees can be allowed to participate when necessary. The development of three-dimensional textbooks includes four stages: front-end analysis, instructional design, resource development and publication of works. This article will explain the first three stages.

(1) Front-end analysis

Front-end analysis is an important basis for determining the selection and development of teaching materials, including learning content analysis and student analysis. The content analysis here not only shows the content analysis of a course, but also the content analysis of the experimental course system of news communication, including "TV camera”, “news photography”, “non-linear editing”, “computer illustration design”, etc. Each course is divided into several specific sub-projects, and each sub-project has overlapping contents. Learning content analysis should be able to clarify the knowledge structure, learning objectives and information module relationship among different courses, so as to determine the organization of teaching materials. Student analysis is the analysis of students' learning style, current knowledge level and group characteristics. The front-end analysis is conducted by professional teachers with teaching 
experience.

(2) Instructional design

According to the results of front-end analysis, the experimental course is designed by teachers. Instructional design includes media design and instructional model design. The design and selection of teaching media should avoid following "multiple" and "new" media, follow the principle of implementing media functions, take teaching objectives as guidance, and select and design media presentation according to the characteristics of teaching content. For example, in the development process of the three-dimensional teaching material "television camera", the learning content is displayed to the visual learners through the micro-video viewing camera base, TV composition, TV lighting and other information points. Teachers can freely integrate teaching resources and apply them to various teaching modes, such as self-study mode on network platform, translation of classroom teaching mode, and acceptance of traditional guidance.

(3) Resource development

The development of experimental teaching resources is a major project involving more personnel, financial resources and financial resources. It is gratifying that most teachers of journalism and communication major have practical experience, and schools are often equipped with teaching facilities such as professional studios, video recording equipment, editing and layout systems. Relying on professional experimental equipment is an appropriate way for teachers, students and teaching assistants to complete the development of teaching materials together. Before development, the standards for resource construction and production should be formulated. During production, teachers should guide the whole process. After completion, a strict inspection and control system should be implemented to ensure the availability of resources. Taking the course of "TV camera" as an example, this paper completes the writing of teachers' and students' video scenes, explains information points to teachers, and gives general control and guidance to teachers after video shooting and novels to students. Providing common teaching resources for teachers and students not only improves the efficiency of teaching material development, but also enables students to learn and apply in the process of participation, so as to understand knowledge and skills practice.

\section{References}

1. Fan Y, Li J. Three-dimensional development of experimental teaching materials of journalism and communication under media convergence (in Chinese). Chinese Editors Journal 2018; (06): 81-85.

2. Liu C. Analysis of the practical teaching reform of news communication under the pattern of media convergence - Taking Journalism Communication College of Xizang Minzu University as an example (in Chinese). Today's Massmedia 2019; (12): 152-155.

3. Tang Z. The innovative path of media major courses teaching under the background of media convergence (in Chinese). Journal of Changchun Normal University, 2018; (07): 176-178.

4. Wang Na. The reform path of journalism and communication education in colleges and universities under the environment of media convergence (in Chinese). Southeast Communication 2018; (05): 134-136. 